\title{
Protecting Biodiversity through Forest Management: Lessons Learned and Strategies for Success
}

\author{
Keith L Kline ${ }^{1,2, a *}$ and Virginia H Dale ${ }^{1,3}$ \\ ${ }^{1}$ Environmental Sciences Division, Oak Ridge National Laboratory, USA \\ ${ }^{2}$ Bredesen Center for Interdisciplinary Research and Graduate Education, University of Tennessee, USA \\ ${ }^{3}$ Department of Ecology and Evolutionary Biology, University of Tennessee, USA
}

Submission: November 09, 2020; Published: November 23, 2020

*Corresponding author: Keith L Kline, Environmental Sciences Division, Oak Ridge National Laboratory, Oak Ridge, TN 37831, USA

Abstract

The strong links among biodiversity, forests, and climate change require that forces affecting them be addressed simultaneously. Here we summarize findings and lessons learned from decades of field work exploring ways to balance conservation with development, while effectively addressing drivers of deforestation and biodiversity loss. Examples are provided for approaches to forest management that support both biodiversity conservation and greenhouse gas mitigation. Causes of deforestation are reviewed and recommendations provided for specific steps that would slow the loss of high conservation-value forests.

Keywords: Biodiversity; Climate change; Forest; Management; Deforestation and degradation

Abbreviations: GHGs: Greenhouse Gases; HCV: High Conservation-Value; NGOs: Non-Governmental Organizations; REDD+: Reducing Emissions from Deforestation and Forest Degradation; UN: United Nations

\section{Introduction}

The United Nations (UN) Summit on Biodiversity held on September 20, 2020, focused on the need for urgent actions to conserve biodiversity in support of more sustainable global development. The Summit highlighted the important role that biodiversity has for making progress toward the UN Sustainable Development Goals and urged key sectors to address causes of biodiversity loss. To help address those issues, this paper reviews relationships among biodiversity, forests, and global climate change. We then provide examples and recommend steps that can be taken to reduce biodiversity losses through stakeholder engagement in improved forest management.

\section{Relationship between Biodiversity, Forestry, and Climate} Change

Biodiversity, forests, and climate change are inextricably and strongly linked [1]. Climate change affects forests directly by influencing species composition, growth rates, and mortality and indirectly by altering the intensity and frequency of disturbances that can modify forest structure, function, and composition $[2,3]$. In turn, forests affect climate change, for about half of the biomass of a tree is made up of carbon. As a tree grows, carbon is sequestered, and, when it dies, decays, or is burned, carbon is released back to the atmosphere.

At the same time, the distribution and abundance of species (biological diversity) are governed by environmental factors, including climate and the ecosystem in which they occur [4]. Forest ecosystems provide distinct light, soil, moisture, and other conditions for the plants and animals that inhabit them. Hence, changes to forests or climate affect biological diversity.

While the extraction and combustion of fossil fuels are responsible for the vast majority of increases in atmospheric carbon and other greenhouse gases (GHGs) and, therefore, climate change forcing, deforestation has contributed about $12 \%$ of total global climate forcing GHGs between 2007 and 2016 [5,6]. However, terrestrial systems are also a large, active, net sink for carbon, meaning that global lands sequester far more carbon

aCopyright Notice: This manuscript has been authored in part by UT-Battelle, LLC, under contract DE-AC05-000R22725 with the US Department of Energy (DOE). The US government retains and the publisher, by accepting the article for publication, acknowledges that the US government retains a nonexclusive, paid-up, irrevocable, worldwide license to publish or reproduce the published form of this manuscript, or allow others to do so, for US government purposes. DOE will provide public access to these results of federally sponsored research in accordance with the DOE Public Access Plan (http://energy.gov/downloads/doe-public-access-plan). 
via photosynthesis in a typical year than volumes emitted from land, i.e., from fires, deforestation, and other changes in land use and cover [7]. Maintaining and increasing net terrestrial carbon sinks requires planning and appropriate management across all landscapes, including forests.

Most terrestrial ecosystems on earth have already been impacted by anthropogenic activities ranging from urban development and agriculture, to extractive enterprises such as mining, logging, and oil and gas field development. Parks and other protected areas are legally established on $16 \%$ of global land area [8]. Despite legal protections, parks in many parts of the world lack the staff and resources required to achieve their goals. Furthermore, many major ecosystem disturbances occur independent of park boundaries. Legally protected areas are increasingly impacted by invasive species, disease, pests, extreme weather events, and other disturbances associated with climate change and human interventions. Therefore, taking responsibility for, and investing in, improved management of ecosystems is critical both for biodiversity conservation and to achieve "natural climate solutions" [9]. Indeed, reforestation and forest management are estimated to offer more than twice the climate mitigation potential of that offered by avoided deforestation alone $[9,10]$.

Better forest management is needed to reverse the negative impacts of human activities in occupied forest landscapes around the globe. Recent analyses underscore that the impacts of longterm forest degradation in the Brazilian Amazon surpass those of deforestation [11]. However, better forest management to reduce degradation requires long-term investments and market incentives that reward specific practices benefiting biodiversity, such as the retention of large deadwood structures [12]. Significant commitments of time and resources are required to identify and protect critical habitats to support biodiversity goals within forest landscapes and to provide ongoing support for stakeholder engagement and shared project goals [13].

The UN Convention on Biological Diversity emphasizes that initiatives for reducing emissions from deforestation and forest degradation (REDD+ ) would both reduce climate-forcing GHG emissions and are an important means to conserve biodiversity $[14,15]$. Other studies in Africa and the United States highlight the need to consider the relationships among land-use options, biodiversity, carbon stocks, and climate in order to conserve high value attributes of forest ecosystems while providing forest services to society $[16,17]$. Stakeholder engagement to develop more sustainable forest and land management plans is also a critical element to enable progress toward multiple goals simultaneously $[17,18]$.

\section{Examples of Forest Management Approaches Supporting Biodiversity and Greenhouse Gas Mitigation}

Many biodiversity conservation initiatives prioritize hot spots [19] or high conservation-value (HCV) areas [20] where forests play key roles not only for habitat to support threatened biodiversity but also for carbon storage and sequestration services that support climate goals. However recent studies emphasize the role of good land management to simultaneously achieve multiple conservation, climate mitigation, and development goals [21,22]. Furthermore, integrated landscape approaches provide a strategy to engage multiple stakeholders to reconcile societal and environmental objectives for the landscape and identify trade-offs and potential synergies for more sustainable and equitable land management [23].

Table 1: Steps to slow the loss of high conservation value (HCV) forests.

\begin{tabular}{|c|c|}
\hline 1. Engage stakeholders & $\begin{array}{l}\text { Engage local communities and other stakeholders to define species of concern and areas of high conservation value } \\
\text { from their perspectives. Stakeholders include local champions, appropriate levels of government, civil society, and } \\
\text { private sector representatives, who need to participate in the process so that they can support the outcomes and can } \\
\text { take next steps to better manage and conserve species and areas with HCVs. }\end{array}$ \\
\hline 2. Evaluate threats & $\begin{array}{l}\text { Identify and evaluate current and potential threats and impacts on species, communities, and ecosystems of concern } \\
\text { under imminent forces of change. Engage local universities, researchers, and experts in this evaluation. }\end{array}$ \\
\hline $\begin{array}{l}\text { 3. Establish conservation } \\
\text { goals }\end{array}$ & $\begin{array}{l}\text { Use participatory methods to establish conservation goals for specific areas, time horizons, and forces of change. } \\
\text { Recognize that areas of special value to stakeholders can be very small or large. Integrated land-use management plans } \\
\text { should acknowledge and respect cultural traditions and resources. Ensure that local stakeholders benefit from the } \\
\text { selected conservation goals, for they must perceive value in conservation efforts to support them. }\end{array}$ \\
\hline $\begin{array}{l}\text { 4. Develop and implement } \\
\text { monitoring systems }\end{array}$ & $\begin{array}{c}\text { Establish clear criteria and indicators for measuring progress toward the achievement of management plan goals. For } \\
\text { HCV forests, include extents and conditions of specific vegetation types or classes, including relevant indicators of } \\
\text { biodiversity. Document baselines and secure resources and training to enable continued monitoring of changes in the } \\
\text { selected indicators. }\end{array}$ \\
\hline $\begin{array}{l}\text { 5. Conduct periodic re- } \\
\text { views of progress }\end{array}$ & $\begin{array}{c}\text { Ensure that annual targets are clear, relevant, and measurable and that progress toward conservation goals is moni- } \\
\text { tored in a timely manner. Prioritize and then apply all available tools to achieve the priority conservation goals. Define } \\
\text { mechanisms, responsibilities, and back-up plans to implement timely corrective actions when monitoring identified } \\
\text { problems. }\end{array}$ \\
\hline
\end{tabular}




\begin{tabular}{|c|c|c|}
\hline $\begin{array}{c}\text { 6. Start small \& build on } \\
\text { successes }\end{array}$ & $\begin{array}{c}\text { Start with a manageable set of goals and indicators that focuses on priorities and hotspots. Apply results of periodic re- } \\
\text { views to identify options for continual improvements using an approach such as the one we document here [18]. With } \\
\text { initial success, additional support is more easily obtained. Consider opportunities to leverage resources by developing } \\
\text { broad-based support for smart development initiatives such as those for infrastructure options that meet people's } \\
\text { needs while avoiding unnecessary losses of forest and biodiversity [e.g.,38]. }\end{array}$ \\
\hline $\begin{array}{c}\text { 7. Identify high-value res- } \\
\text { toration opportunities }\end{array}$ & $\begin{array}{c}\text { Consider opportunities for forest and ecosystem restoration in fresh water/riparian zones or sensitive areas (wet- } \\
\text { lands, mangroves, managed lands that impact downstream reefs and marine ecosystems) as recommended in the } \\
\text { UNEP ecosystem restoration framework [39]. An established program can attract additional resources to support } \\
\text { next steps and restoration. Develop plans that integrate science, indigenous knowledge, and local stakeholders in the } \\
\text { process required to achieve more sustainable outcomes. }\end{array}$ \\
\hline 8. Collaborate & $\begin{array}{c}\text { Build collaborative relationships with local governance and civil society organizations to support the integrated } \\
\text { management plans and goals. Based on steps 1 and 2, develop support networks to monitor projects that threaten HCV } \\
\text { areas, paying special attention to transportation infrastructure. Incorporate field surveys, environmental assessment, } \\
\text { and monitoring activities to identify and protect HCV areas as prerequisite and integral components of large infrastruc- } \\
\text { ture projects. }\end{array}$ \\
\hline
\end{tabular}

An example that merits recognition is community forest management in the Peten Department of Northern Guatemala [2426]. Within the Multiple Use Zone of the Maya Biosphere Reserve, forest management concessions for timber and non-timber products are found to be instrumental in achieving biodiversity, climate, and social development goals. The concessions began operations in 1994 and comprise 400,000 hectares of public lands. Under the terms of the 25-year concessions, a management plan was developed and approved granting community members responsibilities to implement the plan and control deforestation and wildfires. Multiple evaluations over the past two decades by development agencies and environmental non-governmental organizations (NGOs) alike have found that the lands managed by communities are better conserved than two of the neighboring strict conservation areas in the Maya Biosphere Reserve. While the National Parks Laguna del Tigre and Sierra Lacandon were created in 1990 in the same law that established the Maya Biosphere Reserve and are of similar size to the Multiple Use Zone, these two National Parks, under federal government management, have suffered from intensive illegal activities, including logging and land invasions, as well as repeated, extensive wildfires. The challenges in these two parks reflect problems that have been endemic in this frontier region for decades due to a lack of adequate institutional presence and effective governance. While significant improvements in the administration of parks have been achieved since the Maya Biosphere Reserve was created, the community concessions have proven to offer a more effective solution to achieve multiple conservation and development goals. And the community managed concessions have endured despite the persistence of illegal activities, land-tenure conflicts, and other threats to forest ecosystems across the south-central Yucatan peninsula.

\section{Causes of Deforestation}

Identifying the root causes of deforestation is key to developing effective solutions that conserve HCV forests. Satellite imagery and analyses are useful to document changes in land cover but can make it too easy to correlate a current land cover or crop with deforestation. Remote sensing can provide useful information about change but does not tell us why forests are lost.

Context matters. Site-specific drivers of forest degradation and loss must be addressed locally and early if forests are to be conserved. Thus, it is critical to involve all relevant stakeholders in a process that identifies HCV areas and develops plans for their management. Studies on the ground and involving local stakeholders are needed to assess factors responsible for deforestation. Local champions and collaborators are essential to gain an understanding of the context and site-specific processes that lead to forest degradation and changes in land cover. Typically, a combination of actors (people and institutions), policies, and site-specific opportunities (e.g. forest access, resource extraction, land speculation, and markets) drive initial degradation and subsequent deforestation.

It is erroneous to simply assume that a particular product associated with a land use (e.g., beef from pasture) or subsequent land-cover class (e.g., change from forest to grassland) are indicators of the cause of an observed deforestation event. Such land covers and uses following forest degradation or deforestation will change over time in response to many variables that are distinct from the drivers that initiate human incursions and related forest disturbances. As recent experiences in southeast Asia and Brazil illustrate, singling out a specific commodity such as soybeans (Glycine max) or oil from palms (Elaeis spp.) is unlikely to impact deforestation rates unless the root causes are also addressed. Rather than modeling potential relationships such as deforestation that is assumed to be linked to agricultural exports, it is more important to work with communities on the ground to understand and address causal factors and catalysts that enable and precipitate degradation and deforestation processes.

Studies that consider long-term trends find that mining, logging and other extractive enterprises, and governmentfacilitated colonization and development programs have been major drivers of deforestation for centuries. Such programs were associated with different types of products [e.g., rubber (Hevea brasiliensis), tea (Camellia sinensis), rice (Oryza glaberrima or $O$. 
sativa), and palm oil] as well as the exploitation of wildlife, timber, minerals, or fossil fuels. Migration into forest frontiers has also been catalyzed by large infrastructure projects such as dams and hydropower, new industrial centers, ports, and railways. The interactions among policies and customs that make forest lands accessible to the public, allow claims to be made based on cleared land, or otherwise facilitate new development in frontier regions are causes for most observed deforestation.

The International Center for Forestry Research (CIFOR) finds that complex land-tenure conflicts and inadequate forest governance are among the important underlying causes of recent deforestation in Indonesia [27]. Another study of recent changes in nearby Myanmar identifies large corporate concessions on public lands for timber extraction, corresponding infrastructure development, and civil conflicts associated with weak land tenure as the primary causes of deforestation [28]. And, in South America, nearly half of the Peruvian Amazon has been physically disturbed by oil and gas concessions that create extensive new systems for forest access via work camps, hundreds of exploratory wells, and more than 104,000 km of seismic lines [29].

Experiences gained in Guatemala's Maya Biosphere Reserve illustrate the need for clearly defined land tenure, physical presence, technical support, and proper incentives for management. When communities were given clear responsibilities and authorities for management and technical assistance for planning and business development, they were able to improve protection of large tracts of public forest lands under concession agreements. During the same period, neighboring lands in National Parks and the Multiple Use Zone that lacked community concessions continued to be plundered.

Studies based on causal analysis of empirical evidence [30] are consistent with observations of the authors during decades of service working to protect forests and biodiversity in developing nations in Africa, Central America, and South America. While studies differ in location, focus, and types and sources of data analyzed, there is broad consensus that improving roads, bridges, ports, and other means to access hitherto undisturbed forests, combined with opportunities to claim land or extract natural resources, are among the key causes of forest degradation and deforestation. Any large infrastructure project that could increase access to relatively undisturbed forest lands should therefore be analyzed before breaking ground to avoid or minimize negative environmental impacts. Further, any projects that proceed must be monitored to ensure compliance with environmental management and mitigation plans.

\section{Ways to Protect Forests}

Identifying and conserving high-value assets within the $84 \%$ of the world's forests that do not have legal protected status [8] require resources and incentives for analysis and improved management for multiple objectives. Management actions and goals depend on site-specific conditions that help define which areas are best suited for targeted ecosystem services (e.g., water regulation, or specified habitat), sustained harvests of timber or non-timber products, or combinations of services. Political boundaries do not recognize important ecosystem interactions. Therefore, forests that border protected areas merit special consideration in planning, management, and monitoring. And HCV forests within protected areas merit special attention to assure their continued conservation and protection. Analysis and planning should be supported to consider options to conserve species of special concern that are identified with stakeholders and to incorporate a landscape approach to achieve biodiversity conservation goals in tandem with the provision of other products and services [31,32]. The community forest concessions in Guatemala offer excellent examples of management plans that support diverse forest products, ecotourism, and conservation objectives.

Specific actions to support REDD+ and biodiversity conservation goals are recommended in Table 1 . The recommendations are based on research, case studies, and 25+ years of personal field experience working in developing nations to promote natural resource management and the conservation of forests and biodiversity. The eight steps listed in Table 1 have emerged as important ingredients for successful projects that aim to conserve forests and biodiversity while also meeting local development needs. Policy reforms and other interventions that may take longer or involve a wider group of stakeholders are also important to complement local initiatives.

Infrastructures for transportation can be particularly deleterious to protection of HCVs. Road building and road improvements are direct and rapid contributors to losses of HCV forests [33-35]. Many field-based deforestation studies underscore that international financing for large infrastructure projects (dams, bridges, ports, and railways), extractive enterprises, and agricultural expansion has often been directly linked to building roads, creating new access to forest areas, and subsequent loss of HCVA forests and biodiversity [36]. Indeed, roads and corruption are common enabling conditions for the loss of tropical forests and other HCV areas [37]. However, infrastructure can be designed to meet transportation needs while protecting areas of HCV [38].

All lands are disturbed and degraded to varying degrees. Investments, management for restoration, and implementation of strategies that contribute to natural climate solutions $[9,10]$ will support achievement of several SDG targets including those for climate change. Conservation, restoration, and/or improved land management actions that increase carbon storage and/or avoid greenhouse gas emissions can be implemented in forests, wetlands, grasslands, and agricultural lands around the world to provide over one-third of the climate mitigation needed by 2030 to stabilize warming to below $2^{\circ} \mathrm{C}$ [9]. These natural 
solutions along with aggressive reduction in fossil fuel emissions provide ways to deliver on the Paris Climate Agreement as well as improve soil productivity, clean air and water, and maintain biodiversity. In addition, knowledge gained from monitoring and rigorous scientific research should be used to inform continual improvement of forest management and should be reflected in decision-making.

\section{Conclusions}

Examples such as the community forest concessions in the Peten, Guatemala, demonstrate that it is feasible to combine incentives for management, restoration, conservation, production, and monitoring in a single package adapted to local conditions. Stakeholders and local context must be considered when designing ways to conserve biodiversity and forest habitats. Working to improve management and reduce degradation in forest landscapes that are not formally protected provides timely and important interventions to help nations realize targets for climate, biodiversity, and other Sustainable Development Goals. Conservation of HCV forests can be achieved by joining forces with communities, industries, local governments, and other stakeholders to identify and invest in opportunities that improve land management and productivity. Targeted interventions can effectively conserve areas that are high priorities to local and global communities.

\section{Acknowledgements}

Authors thank Esther Parish for her review and comments on the initial draft of this work. KLK's work in South America, Central America and Africa 1980-2008, was funded by the United States Agency for International Development (USAID) in support of Sections 118 and 119 of the US Foreign Assistance Act. Subsequent support for KLK and VHD was provided to Oak Ridge National Laboratory (ORNL) by the USAID Bureau for Food Security, under the terms of Contract No. MTO 069018 "The multi-donor trust fund for the CGIAR" and the CGIAR Research Programs (CRPs) on Wheat and Maize Agri-Food Systems, via a strategic partnership with the International Maize and Wheat Improvement Center (CIMMYT). Current research is supported by the US Department of Energy's Office of Energy Efficiency and Renewable Energy (EERE), Bioenergy Technologies Office (BETO), under award number EE0007088 to ORNL. ORNL is managed by the UTBattelle, LLC, for DOE under contract DE-AC05-000R22725.

\section{References}

1. Dale VH, Joyce LA, McNulty S, Neilson RP (2000) The interplay between climate change, forests, and disturbances. Science of the Total Environment 262(3): 201-204.

2. Joyce LA, et al. (2001) Forests. In Climate Change Impacts: The Potential Consequences of Climate Variability and Change, A report of the National Assessment Synthesis Team of the U. S. Global Change Research Program, Cambridge University Press, Cambridge, UK, pp.
489-524.

3. Joyce L, et al. (2014) Forests. Chapter 7 In Climate Change Impacts in the United States. The Third National Climate Climate Assessment. In: JM Melillo, TC Richmond, GW Yohe (Eds.), US Global Change Research Program, pp. 175-194.

4. National Academy of Sciences (1988) Biodiversity. Washington, DC: The National Academies Press.

5. Tian H, Chaoqun L, Ciais P, Michalak AM, Canadell JG, et al. (2016) The terrestrial biosphere as a net source of greenhouse gases to the atmosphere. Nature 531: 525-228.

6. Le Quéré C, Robbie MA, Pierre F, Stephen S, Julia P, et al. (2017) Global carbon budget 2017 Earth System Science Data Discussions, pp. 1-79.

7. Zhu Z, Piao S, Myneni RB, Huang M, Zeng Z, et al. (2016) Greening the Earth and its Drivers. Nature Climate Change 6: 791-795.

8. Hidalgo DM, Oswalt S, Somanathan E (2015) Status and trends in global primary forest, protected areas, and areas designated for conservation of biodiversity from the Global Forest Resources Assessment 2015 Forest Ecology and Management 352: 68-77.

9. Griscom BW, Adams J, Ellis PW, Houghton RA, Lomax G, et al. (2017) Natural Climate Solutions. Proceedings National Academies Science USA 114(44): 11645-11650.

10. Fargione JE, Bassett S, Boucher T, Bridgham SD, Conant RT, et al. (2018) Natural Climate Solutions for the United States. Science Advances 4: 11.

11. Matricardi EAT, Skole DL, Costa OB, Pedlowski MA, Samek JH, et al. (2020) Long-term forest degradation surpasses deforestation in the Brazilian Amazon. Science 369(6509): 1378-1382.

12. Thorn S, Seibold S, Leverkus AB, Michler T, et al. (2020) The living dead: acknowledging life after tree death to stop forest degradation Frontiers in Ecology and Environment 18(7): 505-512.

13. Kline KL, Martinelli FS, Mayer AL, Medeiros R, Oliveira COF, et al. (2015) Bioenergy and Biodiversity: Key Lessons from the Pan American Region. Environmental Management 56: 1377-1396.

14. United Nations Convention on Biodiversity.

15.FAO (2020) Reducing Emissions from Deforestation and Forest Degradation.

16. Buotte PC, Law BE, Ripple WJ, Berner LT (2020) Carbon sequestration and biodiversity co-benefits of preserving forests in the western United State. Ecological Applications 30(2): e02039.

17. Capitani C, Olivia N, John PP, Neil B, Kusaga M, et al. (2015) Exploring the future land use-biodiversity-climate nexus in East Africa: an application of participatory scenario analysis. GLP News. pp. 10-13.

18. Dale VH, Kline KL, Parish ES, Eichler SE (2019) Engaging stakeholders to assess landscape sustainability. Landscape Ecology 34: 1199-1218.

19. Critical Ecosystem Partnership Fund (2020) Biodiversity hotspots defined.

20. HCV (2020) HCV network's library.

21. Sunderland TCH, Rowland D (2019) Forests, Land Use, and Challenges to Climate Stability and Food Security. Chapter 6 in Sustainable Food and Agriculture: An Integrated Approach, Academic Press, pp. 95-116.

22. Dale VH, Efroymson RA, Kline KL (2011) The land use - climate change - energy nexus. Landscape Ecology 26(6): 755-773.

23. Reed J, Ros Tonen MAF, Sunderland TCH (2020) Operationalizing integrated landscape approaches in the tropics. Center for International 
Forestry Research.

24. Gretzinger SP (1998) Community Forest Concessions: An Economic Alternative for the Maya Biosphere Reserve in the Petén, Guatemala. Chapter 8 in Timber Tourists, and Temples: Conservation and development in the Maya forest of Belize, Guatemala, and Mexico. Island Press, pp. 111-124.

25. Radachowsky J, Ramos VH, McNab R, Baur EH, Kazakovd N (2012) Forest concessions in the Maya Biosphere Reserve, Guatemala: A decade later. Forest Ecology and Management 268: 18-28.

26. Hodgdon BD, Hayward J, Samayoa O (2013) Putting the Plus First: Community Forest Enterprise as the Platform for REDD+ in the Maya Biosphere Reserve, Guatemala. Tropical Conservation Science 6(3): 365-383.

27. Forest News (2019) Palm oil's complex land conflicts.

28. Lim CL, Prescott GW, De Alban JDT, Ziegler AD, Webb EL (2017) Untangling the proximate causes and underlying drivers of deforestation and forest degradation in Myanmar. Conservation Biology 31(6): 1362-1372.

29. Orta Martinez M, Finer M (2010) Oil frontiers and indigenous resistance in the Peruvian Amazon. Ecological Economics 70(2): 207-218.

30. Efroymson RA, Kline KL, Angelsen A, Verburg PH, Dale VH, et al. (2016) A causal analysis framework for land-use change and the potential role of bioenergy. Land Use Policy 59: 516-527.
31. Boiral O, Heras Saizarbitoria I (2017) Managing Biodiversity Through Stakeholder Involvement: Why, Who, and for What Initiatives? J Bus Ethics 140: 403-421.

32. Sayer J, Sunderland T, Ghazoul J, Pfund JL, Sheil D, et al. (2013) Ten principles for a landscape approach to reconciling agriculture, conservation, and other competing land uses. Proceedings National Academies Science USA 110(13): 8349-8356.

33. Forman RT, Sperling D, Bissonette JA, Cleverger AP, Cutshall CD, et al. (2003) Road Ecology: Science and Solutions. Island Press.

34. Sloan S, Alamgir M, Campbell MJ, Setyawati T, Laurance WF, et al. (2019) Development corridors and remnant-forest conservation in Sumatra, Indonesia. Tropical Conservation Science 12: 1-9.

35. Fearnside PM (2005) Deforestation in Brazilian Amazonia: History, Rates, and Consequences. Conservation Biology 19(3): 68-688.

36. Fearnside PM (1987) Deforestation and International Economic Development Projects in Brazilian Amazonia. Conservation Biology 1(3): 214-221.

37. Simon F (2020) US scientist: 'Roads and corruption' are big drivers of deforestation.

38. Vilela T, Harb AM, Bruner A, Arruda VLS, Ribeiro V, et al. (2020) A better Amazon road network for people and the environment. Proceedings National Academies Science USA 117(13): 7095-7102.

39. UNEP (2019) UN Decade on Ecosystem Restoration. 